\title{
Contractuele vaccinatieplichten, coronaclausules en wijziging van overeenkomsten
}

\author{
Contractsvrijheid in tijden van corona
}

\author{
Prof. mr. H.N. Schelbaas*
}

\begin{abstract}
1 Inleiding
Het coronavirus heeft de wereld nu bijna anderhalf jaar in zijn macht. ${ }^{1}$ Weliswaar opent de maatschappij zich langzaamaan weer, worden de coronabeperkingen verlicht en komt ook de economie weer op gang, maar de effecten van de coronacrisis zijn nog goed voelbaar, op de maatschappij, de economie en daarmee ook op het recht. De voorbeelden zijn talloos. De overheid vaardigde vele besluiten uit, waaronder sluiting van winkels en horeca, verbod van het uitoefenen van contactberoepen en de invoering van de avondklok, waarbij wel de bestuursrechtelijke vraag werd gesteld of dat van een voldoende deugdelijke juridische basis was voorzien. ${ }^{2}$ Deze maatregelen hadden tot gevolg dat huurovereenkomsten onder druk kwamen te staan, omdat bedrijfsmatige huurders van bijvoorbeeld horecapanden geen clientèle meer konden ontvangen, maar wél de volledige huurprijs moesten betalen. ${ }^{3}$ In het procesrecht werd noodgedwongen gebruik gemaakt van digitale zittingen, terwijl in het ondernemingsrecht aandeelhouders- en ledenvergaderingen eveneens digitaal plaatsvonden. ${ }^{4}$ Het arbeidsrecht wordt ook geconfronteerd met coronagerelateerde kwesties, zoals ten aanzien van de vraag of een werkgever loon moet doorbetalen als een werknemer naar een code-oranje-land op vakantie is geweest en daarna in qua-
\end{abstract}

Prof. mr. H.N. Schelhaas is hoogleraar privaatrecht aan de Erasmus School of Law, Erasmus Universiteit Rotterdam, en redacteur van dit tijdschrift.

1. Voor enige voorbeelden van de sociaaleconomische weerslag van de corona-crisis: W.H. van Boom, Coronaprivaatrecht 2020-2021, RMThemis 2021, afl. 3, p. 128-131.

2. De rechtbank Den Haag oordeelde bij vonnis van 16 februari 2021, ECLI:NL:RBDHA:2021:1100, dat dat niet het geval was, maar dit vonnis hield in hoger beroep geen stand: Hof Den Haag 26 februari 2021, ECLI:NL:GHDHA:2021:285. Uiteindelijk is de wettelijke basis verstevigd: Tijdelijke wet beperking vertoeven in de openlucht covid-19, Stb. 2021, 85 (Kamerstukken 35732).

3. Z.H. Duijnstee-van Imhoff, Huurrecht en de coronacrisis, MvV 2020, afl. 12, p. 439-446.

4. Zie o.m. M. van Olffen \& C.R. Nagtegaal, Tijdelijke wet COVID-19 vergaderen rondom het coronavirus, Ondernemingsrecht 2020, afl. 7 , p. 323-332; C.R. Nagtegaal, Het coronavirus en de algemene vergadering, Ondernemingsrecht 2020, afl. 7, p. 333-337. rantaine moet blijven. Verder doemt de vraag op of een werkgever zijn werknemers kan verplichten naar het werk te komen, en of hij een zorgverplichting heeft bij de inrichting van een thuiswerkplek. ${ }^{5}$

Ook op het algemene contractenrecht hebben de coronamaatregelen invloed (gehad). Zo werd direct de vraag relevant of de coronacrisis een onvoorziene omstandigheid was, op grond waarvan een contract kan worden gewijzigd of ontbonden, en werd afgevraagd of een partij die tot nakoming werd gedwongen maar door de coronacrisis niet kan nakomen, zich op overmacht kan beroepen. In deze bijdrage richt ik mij vanuit het beginsel van de contractsvrijheid op de invloed van de coronamaatregelen op contracten: rechtvaardigen de coronamaatregelen dat een inbreuk wordt gemaakt op de contractsvrijheid? ${ }^{6}$ Ik ga hierbij in op de wat mij betreft drie belangrijkste aspecten. In de eerste plaats besteed ik aandacht aan de actuele vraag of private partijen in hun contract mogen opnemen dat de wederpartij gevaccineerd of getest is op het coronavirus voordat zij diensten kan afnemen (par. 2). Is dat op grond van het beginsel van de contractsvrijheid toelaatbaar, of moeten hier grenzen aan worden gesteld? In de tweede plaats ga ik in op de wijziging van contracten op grond van het leerstuk van onvoorziene omstandigheden (par. 3). Tot slot bespreek ik de vraag in hoeverre coronaclausules, dus clausules die contractueel vastleggen wat de juridische consequenties zijn van coronamaatregelen, geldig en afdwingbaar zijn (par. 4). Ik sluit af met een reflectie (par. 5).

5. A.R. Houweling, Corona en arbeidsrecht: hoe NOW verder met loon en werkplek?!, MvV 2020, afl. 9, p. 315-324.

6. Voor andere contractenrechtelijke consequenties van de coronacrisis, en meer specifiek de vraag naar remedies indien de wederpartij niet nakomt door een oorzaak verbonden aan coronabeperkingen, zie o.m. H.N. Schelhaas \& J.H.M. Spanjaard, Contract en coronacrisis, NJB 2020, afl. 14, p. 956-969; M.R. Ruygvoorn, Kan ik van mijn overeenkomst af met een beroep op de coronacrisis?, NJB 2020, afl. 14, p. 970-976. 


\section{Privaatrechtelijke privileges voor gevaccineerden?}

\subsection{Mensenrechten, de overheid en vaccinatieplicht}

Een eerste en thans heel actueel punt dat gerelateerd is aan het beginsel van de contractsvrijheid is de vraag of private partijen mogen eisen dat een wederpartij tegen COVID-19 is gevaccineerd of op het coronavirus is getest voordat zij van een dienst - zoals het bezoeken van een voetbalwedstrijd of een ander evenement - gebruik mag maken. Niet iedereen wil gevaccineerd worden en bovendien is nog niet elke Nederlander al volledig gevaccineerd. Daarnaast is het mogelijk dat in de toekomst nieuwe vaccinatieronden moeten plaatsvinden, bijvoorbeeld tegen nieuwe varianten van het COVID-19-virus, waarbij eveneens voorstelbaar is dat een deel van de bevolking enige tijd niet volledig gevaccineerd is en om deze reden geen toegang krijgt tot evenementen. De vraag of een contractenrechtelijke vaccinatieplicht mag worden gesteld, behoudt dus nog wel enige tijd actualiteitswaarde.

Als de overheid een dergelijke eis stelt voor het gebruik maken van vitale of basale publieke diensten, dan staat dat op gespannen voet met het recht op eerbiediging van privé-, gezins- en familieleven, de lichamelijke integriteit en het recht op privacy, en kan dit zodoende strijd opleveren met mensenrechten (onder meer art. 8 lid 1 EVRM en art. 1 Grondwet). ${ }^{7}$ Hierbij is van belang dat Nederland geen vaccinatieplicht kent en dat vaccinatie op basis van vrijwilligheid geschiedt. ${ }^{8}$ Als een overheid (bewijs van) een vaccinatie of een negatieve coronatest verplicht stelt voor het gebruik maken van vitale diensten - onderwijs, zorg enzovoort -, dan dwingt zij haar burgers in wezen tot handelingen die strijdig zijn met de lichamelijke integriteit en dus met fundamentele (mensen)rechten. Op zich mag de overheid deze rechten beperken, maar dan is een wettelijke basis vereist en moet zo'n beperking noodzakelijk, proportioneel en effectief zijn voor het doel dat wordt nagestreefd. ${ }^{9} \mathrm{Om}$ in die wettelijke grondslag te voorzien is inmiddels een wetsvoorstel aanhangig ten aanzien van de toegang tot sport- en jeugdactiviteiten, culturele instellingen, evenementen, restaurants en overige horeca. Het is de bedoeling dat voor het middelbaar beroepsonderwijs en het hoger onderwijs bij algemene maatregel van bestuur regels kunnen worden gesteld met betrekking tot de inrichting van het onderwijs. Meer specifiek: zo kan worden bepaald dat met behulp van testbewijzen fysiek onderwijs mag worden genoten, zodat aan

7. M.A.J.M. Buijsen, Wat te doen met vaccinatieweigeraars?, RMThemis 2020, afl. 3, p. 148.

8. Zie nader Buijsen 2020, p. 146-149.

9. Wat betreft inbreuk op art. 8 lid 1 EVRM door de overheid volgt het vereiste van een wettelijke basis uit het tweede lid: inbreuk op dat recht is alleen toegestaan (1) voor zover deze bij de wet is voorzien en $(2)$ in een democratische samenleving noodzakelijk is (3) in het belang van de nationale veiligheid, de openbare veiligheid of het economisch welzijn van het land, het voorkomen van wanordelijkheden en strafbare feiten, de bescherming van de gezondheid of de goede zeden of de bescherming van de rechten en vrijheden van anderen. meer studenten op grotere schaal onderwijs gegeven kan worden. ${ }^{10}$

\subsection{Belangen bij contractenrechtelijke vaccinatieplichten}

Maar of en in hoeverre privaatrechtelijke partijen in hun contracten mogen bedingen dat een persoon alleen diensten mag afnemen als hij laat zien dat hij gevaccineerd is of negatief is getest, is een ander verhaal. Hier zijn mijns inziens in ieder geval vier relevante verschillen te onderkennen, die deze situatie anders maken dan die waarin de overheid een vaccinatieof testbewijs eist.

In de eerste plaats geldt op de private markt natuurlijk het beginsel van de contractsvrijheid, hetgeen ertoe leidt dat partijen in beginsel vrij zijn om te bepalen met wie zij contracteren, en ook welke inhoud zij aan hun contractuele verhouding geven. Het staat een partij in beginsel dus ook vrij om een vaccinatieplicht of de overlegging van een testbewijs in haar contract op te nemen.

In de tweede plaats gaat het hier in de regel niet om het gebruik maken van basale of essentiële publieke diensten, ${ }^{11}$ maar om diensten - evenementen, concerten, voetbalwedstrijden enzovoort - die niet noodzakelijk zijn, maar die een deel van de bevolking wel graag wil afnemen. Men zou kunnen zeggen dat het hier vaker gaat om een vrijere keuze om al dan niet een dergelijke dienst af te nemen dan bijvoorbeeld bij een publieke onderwijsdienst. Dat maakt verschil, omdat een vaccinatieplicht bij een publieke essentiële dienst dus eerder leidt tot een feitelijke vaccinatiedwang.

In de derde plaats geldt weliswaar dat een verplichting om zich te laten testen of te vaccineren en daar bewijs van te laten zien, strijdig kan zijn met het recht op privacy en lichamelijke integriteit (art. 8 EVRM en art. 11 Grondwet), maar dat deze grondrechten in beginsel geen horizontale directe werking hebben tussen private partijen. Oftewel, een private partij kan daar niet direct een beroep op doen jegens haar private wederpartij (directe horizontale werking), terwijl een burger zich hier jegens de overheid wel direct op kan beroepen (verticale werking). ${ }^{12}$ Een argument voor dit verschil is dat grondrechten zijn bedoeld om de burger te beschermen tegen de almachtige overheid die deze algemene belangen moet beschermen, en niet zozeer jegens andere private partijen. Wel

10. Wetsvoorstel Tijdelijke wet testbewijzen covid-19, Kamerstukken II 2020/21, 35807, nr. 2.

11. Een private partij kan natuurlijk wel publieke diensten uitvoeren, zoals in het onderwijs of de zorg.

12. Zie nader H.N. Schelhaas, Redelijkheid en billijkheid (Mon. BW nr. A5), Deventer: Wolters Kluwer 2017/6; O. Cherednychenko, Fundamental Rights, Contract Law and the Protection of the Weaker Party (diss. Utrecht), München: Sellier 2007; J.M. Emaus, Handhaving van EVRMrechten via het aansprakelijkheidsrecht (diss. Utrecht), Den Haag: Boom Juridische uitgevers 2013; C. Mak, Fundamental Rights in European Contract Law (diss. Amsterdam UvA), Alphen aan den Rijn: Kluwer Law International 2007; J.M. Smits, Constitutionalisering van het vermogensrecht (preadvies NVvR), Deventer: Kluwer 2003. 
is mogelijk dat grondrechten indirect tussen private partijen invloed hebben, dus indirecte horizontale werking hebben. ${ }^{13}$ Dat kan in het contractenrecht bijvoorbeeld zijn beslag krijgen via de open norm van de redelijkheid en billijkheid (art. 6:248 lid 1 en $2 \mathrm{BW})^{14}$ of openbare orde en goede zeden (art. 3:40 $\mathrm{BW})$. In de rechtspraak wordt deze indirecte doorwerking van mensenrechten ook aanvaard. ${ }^{15}$

In de vierde plaats is ook hier van belang dat in Nederland geen vaccinatieplicht geldt. Het opnemen van een contractuele bepaling dat een partij zich moet hebben gevaccineerd of moet zijn getest voordat zij kan deelnemen aan een evenement, betekent nog niet dat hiermee feitelijk een vaccinatieplicht wordt gerealiseerd. Maar als dat op grote schaal gebeurt en dit betekent dat een partij in feite niet meer kan deelnemen aan het maatschappelijk leven zonder gevaccineerd te zijn, dan leidt dat in wezen wel tot een indirecte vaccinatieplicht. Dat kan strijdig zijn met de idee dat natuurlijke personen zélf kunnen en mogen beslissen of zij gevaccineerd willen worden, en ook dat kan invloed hebben op grenzen die aan de contractsvrijheid worden gesteld.

Deze elementen hebben consequenties voor de vrijheid om contractuele vaccinatieplichten te bedingen. Ik ga daar nader op in.

\subsection{De grenzen van de contractsvrijheid bij vaccinatieplichten}

Uitgangspunt is natuurlijk het beginsel van de contractsvrijheid. Dat betekent in beginsel dat zo'n contractuele vaccinatie- of testverplichting geldig en afdwingbaar is. Maar deze vrijheid kent haar beperkingen, die verband houden met de hiervoor geschetste grond- en mensenrechten die hier in het geding zijn, en de gedachte dat geen indirecte of feitelijke vaccinatieplicht mag ontstaan. Die begrenzingen aan een contractuele inentings- of testverplichting vinden hun grondslag in de beperkende werking van de redelijkheid en billijkheid ex

13. Zie o.m. Asser/Hartkamp 3-I 2019/228 en 229 voor het EVRM en voor horizontale werking van grondrechten uit het EU Handvest 231f; Asser/ Sieburgh 6-III 2018/59; F.J. de Vries, De overeenkomst in het algemeen (Mon. BW nr. B54), Deventer: Wolters Kluwer 2016/15, die bespreekt dat de handhaving van grondrechten in contractuele rechtsverhoudingen soms in specifieke wetten is neergelegd.

14. De beperkende werking van de redelijkheid en billijkheid leidt er dan toe dat op een beding geen beroep kan worden gedaan, mede gezien strijdigheid met fundamentele rechten. De aanvullende werking heeft als resultaat dat een verplichting aan een contract wordt toegevoegd omdat fundamentele rechten dat vergen. Voor een voorbeeld van deze laatste werking: HR 12 december 2003, ECLI:NL:HR:2003:AL8442, NJ 2004/117 (Verplichte aidstest), waar bij een medische behandelingsovereenkomst op grond van de redelijkheid en billijkheid een verplichte aidstest van een patiënt werd aangenomen.

15. Voor voorbeelden zie Vriend, in: GS Verbintenissenrecht, art. 6:2 BW, aant. 1.73 . art. 6:248 lid $2 \mathrm{BW}^{16}$ en de grenzen die art. 3:40 BW stelt: een overeenkomst of beding mag niet strijdig zijn met de openbare orde en goede zeden. De grens van de openbare orde en goede zeden leidt tot nietigheid of vernietigbaarheid van het beding (art. 3:40 lid 1 en $2 \mathrm{BW}$ ), zodat het beding in feite non-existent is of wordt. Een en ander leidt ertoe dat in een bepaald geval geen beroep kan worden gedaan op een contractuele vaccinatie- en/of testbepaling (art. 6:248 lid 2 BW), respectievelijk dat een beding van rechtswege nietig of vernietigbaar is (art. 3:40 BW).

Beide routes vergen een afweging van de specifieke feiten en omstandigheden van het geval. Bij de redelijkheid en billijkheid moet worden afgevraagd of het beroep op een vaccinatieof testbewijs naar maatstaven van redelijkheid en billijkheid echt onaanvaardbaar is, hetgeen terughoudend wordt getoetst. ${ }^{17}$ De 'redelijkheid en billijkheid' is een open norm, maar wordt onder meer ingevuld door art. 3:12 BW. Zo zijn bij de invulling van de redelijkheid en billijkheid algemeen erkende rechtsbeginselen en in Nederland levende rechtsovertuigingen van belang. ${ }^{18}$ Het kan worden gesteld dat ook grondrechten daartoe behoren, omdat zij waarden die maatschappelijk van belang worden geacht reflecteren. Dat biedt een goede opening om de onwenselijkheid van een algemene feitelijke vaccinatieplicht en strijdigheid met grond- en mensenrechten mee te wegen bij de vraag of een beding naar maatstaven van redelijkheid en billijkheid onaanvaardbaar is. ${ }^{19}$ $\mathrm{Bij}$ art. 3:40 BW moet worden getoetst of een vaccinatie- of coronatestbeding strijdig is met de openbare orde of goede zeden. Voorstelbaar is bijvoorbeeld dat als door een contractuele vaccinatieplicht feitelijk een algemene vaccinatieplicht ontstaat omdat zo een deel van de bevolking geen toegang heeft tot het maatschappelijk leven, dit schuurt met de openbare orde. Ook de openbare orde en goede zeden zijn open normen, die zich moeilijk op voorhand laten inkaderen.

Duidelijk is wel dat de belangen van beide contractspartijen moeten worden meegewogen. ${ }^{20}$ Het belang van de afnemer van de dienst die niet gevaccineerd wenst te worden en ook

16. Verder kan ook de vernietigbaarheid van algemene voorwaarden omdat een beding 'onredelijk bezwarend' is, een rol spelen, maar dat artikel bespreek ik niet expliciet: de open norm van art. 6:248 lid 2 BW is materieel gelijkluidend aan die van art. 6:233 sub a BW. Daar waar ik spreek over art. 6:248 lid 2 BW, geldt dit mutatis mutandis voor art. 6:233 sub a $\mathrm{BW}$. In buitencontractuele verhoudingen is de maatschappelijke betamelijkheid van art. 6:162 BW van belang.

17. Schelhaas $2017 / 33$.

18. Schelhaas $2017 / 5$.

19. Voor een voorbeeld: Hof Amsterdam 24 februari 2009, ECLI:NL:HR: 2009:BH6413, NJ 2010/657 (tussenarrest) en Hof Amsterdam 29 september 2009, ECLI:NL:HR:2009:BL6547, NJ 2010/658 (eindarrest). Het betrof hier de vraag of een contractueel schotelantenneverbod naar maatstaven van redelijkheid en billijkheid onaanvaardbaar was in verband met art. 10 EVRM (recht op informatie). Het hof kent aan dit mensenrecht werking toe via de toetsing aan de open norm van de beperkende werking van de redelijkheid en billijkheid.

20. Uit de Vodafone/ETC-uitspraak (HR 19 oktober 2007, ECLI:NL:HR: 2007:BA7024, NJ 2007/565) volgt ook dat contractspartijen rekening moeten houden met elkaars belangen. 
geen coronatest wil laten afnemen, is helder: hij wil een ongelimiteerde afname van de dienst en wil geen inbreuk op zijn lichamelijke integriteit. Ook het belang van de afnemer die wél gevaccineerd wil worden maar nog niet aan de beurt is, is duidelijk: hij wil simpelweg toegang tot een evenement.

Het belang van de wederpartij schuilt onder meer in een economisch belang, dat verband houdt met de thans kwetsbare maatschappelijke gezondheidssituatie: met coronatest- en vaccinatieplichten kan hij sneller en op grotere schaal zijn economische activiteiten hervatten, waarbij de kans op een gezondheidsrisico wordt beperkt. Hierbij kan ook een directer gezondheidsbelang spelen: de ondernemer wil niet verantwoordelijk zijn en aansprakelijk kunnen worden gehouden voor grootschalige corona-uitbraken, omdat hij zijn klanten niet heeft getest op een corona-inenting of geen coronatest heeft geëist. Dat zijn gelegitimeerde belangen die wat mij betreft in het huidige stadium van de crisis zwaar wegen. De economie start net op, veel bedrijven zijn economisch zwaar geraakt, en het is dus ook van maatschappelijk belang dat bedrijven weer economische activiteiten gaan verrichten. Met privaatrechtelijke vaccinatieplichten of testbewijzen is daarmee ook een algemener economisch belang gediend: een noodzakelijke injectie in de Nederlandse economie. De enige manier waarop dat thans kan - nu nog niet iedereen is ingeënt en besmettingen blijven bestaan -, is door vaccinatie- en testbewijzen te vragen.

Interessant is in dit verband dat de Gezondheidsraad een advies heeft uitgebracht ten aanzien van vaccinatieplichten aan de Minister van Volksgezondheid, Welzijn en Sport (VWS). De Gezondheidsraad concludeert het volgende:

'Private partijen moeten een belangenafweging maken en kunnen aantonen dat het vaccinatiebewijs een gerechtvaardigd doel dient, noodzakelijk is om dat doel te bereiken en voldoet aan de eisen van subsidiariteit en proportionaliteit. $^{21}$

Dat is mijns inziens een veel te strenge maatstaf, die conflicteert met het contractenrechtelijke kader en de begrenzingen van de contractsvrijheid die volgen uit de wet en rechtspraak. Het uitgangspunt is immers de contractsvrijheid, zodat partijen in beginsel een vaccinatieplicht mogen overeenkomen, zonder de eisen die de Gezondheidsraad wil stellen. Of de grenzen aan de contractsvrijheid in een concreet geval een halt toebrengen aan een contractuele vaccinatie- of testverplichting is afhankelijk van de feiten en omstandigheden van het geval en vergt een belangenafweging. Maar dat is iets anders dan de strenge eisen die de Gezondheidsraad op voorhand wil stellen. Bij de belangenafweging kan wat mij betreft een aantal factoren een rol spelen.

21. Gezondheidsraad, Ethische en juridische afwegingen COVID-19-vaccinatie, 4 februari 2021, www.gezondheidsraad.nl/documenten/adviezen/ 2021/02/04/ethische-en-juridische-afwegingen-covid-19-vaccinatie.
Een eerste element dat een belangrijke rol speelt, is het gegeven dat een vaccinatieplicht inbreuk maakt op het grondrecht van de lichamelijke integriteit. In zoverre kan worden meegegaan met een deel van de bovenstaande maatstaf van de Gezondheidsraad (het gerechtvaardigd doel) dat van een partij die deze contractuele verplichting oplegt, moet worden verwacht dat zij kan aangeven dat daar een reden voor is. Zolang het virus nog rondwaart en een contractuele vaccinatieplicht of een testbewijs besmettingen en het herleven van de pandemie kan voorkomen, dan is dat mijns inziens al snel het geval. Als daar een specifieke individuele reden aan kan worden toegevoegd (de ondernemer kan bijvoorbeeld zijn bedrijfsactiviteiten verbreden), dan kan wat mij betreft een vaccinatieof testverplichting bezwaarlijk worden beperkt. Wel merk ik op dat de belangenafweging anders kan uitpakken als bijvoorbeeld volledige groepsimmuniteit is bereikt, veruit het grootste deel van de bevolking is gevaccineerd, de medische consequenties van een COVID-19-besmetting mild blijken te worden, en de volksgezondheid dus niet of zeer beperkt wordt ondersteund met een vaccinatie- of testverplichting. In zo'n geval bestaat een beperkte algemene en individuele reden voor een dergelijke vaccinatie- of testverplichting en komen de grenzen van art. 6:248 lid 2 of 3:40 BW in zicht. Interessant is in dit verband dat het Europees Hof voor de Rechten van de Mens (EHRM) in een zaak tussen de Tsjechische overheid en een aantal van haar ingezetenen heeft geoordeeld dat een vaccinatieplicht voor kinderen in een kinderdagverblijf de toets der kritiek kan doorstaan, mede omdat de publieke gezondheidszorg prevaleert boven het recht op de bescherming van de persoonlijke levenssfeer (art. 8 EVRM). ${ }^{22}$ De volksgezondheid werd hier als een voldoende legitiem doel gezien. In het verlengde hiervan is een contractenrechtelijke vaccinatie- of testverplichting die nodig is om gezien de huidige gezondheidssituatie economische activiteiten te ontplooien, mijns inziens in beginsel legitiem.

Een andere relevante factor is mijns inziens de omstandigheid dat een private partij náást een vaccinatieplicht ook de mogelijkheid biedt om met een gecertificeerde coronatest de dienst af te nemen. In zo'n geval is de contractuele vaccinatieplicht minder bezwaarlijk: er bestaat immers een redelijk en minder invasief alternatief. Ook hier blijft een vaccinatieplicht, als daar een reden voor is, wat mij betreft eenvoudiger overeind.

Een derde relevant punt is het antwoord op de vraag of alle partijen zich al volledig hebben kunnen inenten. ${ }^{23}$ Als dat niet zo is, dan kan worden betoogd dat strijdigheid bestaat met het gelijkheidsbeginsel, want het is soms min of meer toevallig wanneer een bepaalde (leeftijds)groep aan de beurt is voor een vaccinatie, en dat hebben partijen niet in eigen hand. Dat

22. EHRM 8 april 2021, ECLI:CE:ECHR:2021:0408JUD004762113 (Vavricka c.s./de Tsjechische Republiek). Een wetsvoorstel om kinderen bij de kinderopvang die niet deelnemen aan het Rijksvaccinatieprogramma te mogen weigeren, is thans aanhangig bij de Eerste Kamer: Kamerstukken I 2019/20, 35049, A.

23. Kamerstukken I 2019/20, 35049, A, p. 22. 
betekent mijns inziens echter niet dat geen vaccinatiebewijzen kunnen of mogen worden geëist, want dan blijven de economie en maatschappij grotendeels op slot totdat de hele bevolking een vaccin heeft en geen besmettingsgevaar meer bestaat, en dat is mijns inziens (inmiddels) ook een rechtens te respecteren belang. Wel zal in zo'n situatie een alternatief moeten worden geboden om de afwezigheid van een coronabesmetting vast te stellen (bijvoorbeeld een PCR-test).

In de vierde plaats moet ervoor worden gezorgd dat de eisen die private partijen stellen om te verifiëren of een wederpartij is gevaccineerd, voldoen aan privacywetgeving, ${ }^{24}$ en dat moet worden gegarandeerd dat persoonsgegevens niet kunnen worden gedeeld. Zodra dat niet kan worden gerealiseerd, kan een vaccinatieplicht de toets van art. 6:248 lid 2 BW niet passeren, omdat hier inbreuk wordt gemaakt op een heel wezenlijk belang.

\subsection{Conclusie}

$\mathrm{Al}$ met al meen ik dat zolang de bevolking nog niet afdoende is gevaccineerd en het virus nog rondwaart in de Nederlandse samenleving, in beginsel voldoende reden bestaat om een contractuele vaccinatieplicht te hanteren of een testbewijs te eisen. Maar op een gegeven moment komt wel een omslagpunt. Als COVID-19 niet meer een reëel gezondheidsprobleem vormt, besmettingen zeer zijn teruggelopen en in feite een soort groepsimmuniteit ontstaat, en de gevolgen van een besmetting ook minder ernstig zijn, dan kan de belangenafweging anders uitvallen en kan niet zomaar in algemene zin een vaccinatie- of testbewijs worden geëist. Maar wanneer dat kantelpunt ontstaat, is moeilijk op voorhand te bepalen. Het blijft gaan om een afweging van belangen.

\section{Wijziging van contracten als gevolg van onvoorziene omstandigheden ${ }^{25}$}

\subsection{Algemeen kader}

Een tweede punt dat de contractsvrijheid bedreigt, is de rol van de onvoorziene omstandigheden. Een duidelijk uitgangspunt in het contractenrecht is dat overeenkomsten moeten worden nagekomen (art. 3:296 BW). Maar als door omstandigheden waar partijen geen rekening mee hebben gehouden het contractuele evenwicht fundamenteel wordt verstoord, dan biedt art. 6:258 BW de mogelijkheid om een contract aan te passen aan de nieuwe werkelijkheid of te ontbinden. ${ }^{26} \mathrm{Het}$ artikel is een species van de beperkende werking van de rede-

24. Kamerstukken I 2019/20, 35049, A, p. 23-24.

25. Deze paragraaf is gebaseerd op het artikel van Spanjaard en mijzelf (Schelhaas \& Spanjaard 2020), maar is anders van opzet, aangevuld met een antal nieuwe onderwerpen en ook geactualiseerd en van recente rechtspraak voorzien.

26. Waar ik in het vervolg 'wijzigen' schrijf, bedoel ik ook de ontbindingsmogelijkheid van de rechter. lijkheid en billijkheid. ${ }^{27}$ De coronacrisis heeft deze regeling, die voorheen niet vaak werd toegepast, afgestoft: in de rechtspraak wordt regelmatig met succes een beroep gedaan op art. 6:258 BW in verband met de gevolgen van de exceptionele coronacrisis. Dat is wat mij betreft gerechtvaardigd, omdat de coronacrisis niet zomaar een puur economische crisis is zoals die in 2007, maar veel verdergaand is, en ook een ander karakter en andere oorsprong heeft. Die oorsprong is immers gelegen in de volksgezondheid en een zeer grootschalige (mondiale) pandemie, die uit het oogpunt van volksgezondheid noopte tot grootschalig overheidsoptreden, resulterend in hele bedrijfstakken en grote delen van het maatschappelijk leven die volledig stil werden gelegd. ${ }^{28}$ Deze extreme omstandigheden kunnen niet tot het normale ondernemersrisico worden gerekend.

Om die reden is het leerstuk van de onvoorziene omstandigheden een nieuw leven ingeblazen. Art. 6:258 lid 1 BW bepaalt dat de rechter op verzoek van een van de partijen ${ }^{29}$ een contract kan aanpassen, als sprake is van een onvoorziene omstandigheid die van dien aard is dat ongewijzigde instandhouding naar maatstaven van redelijkheid en billijkheid niet kan worden verwacht (art. 6:258 lid 1 BW). Volgens lid 2 mag deze omstandigheid niet voor rekening en risico komen van degene die zich daarop beroept. Ik loop de vereisten die uit dit artikel voortvloeien af.

\subsection{Onvoorziene omstandigheid: toekomstig en niet verdisconteerd}

Van een onvoorziene omstandigheid is sprake als die ten tijde van de contractsluiting in de toekomst ligt, én het contract niet heeft voorzien in deze omstandigheid: er is geen regeling voor getroffen. De vraag of een omstandigheid voorzienbaar is, is dus niet het ijkpunt. ${ }^{30}$

Het eerste element, de toekomstige omstandigheid, levert bij coronacrisiszaken niet vaak problemen op. Ten aanzien van vóór maart 2020 gesloten contracten - toen de eerste dode viel en de eerste overheidsmaatregelen werden afgekondigd wordt de coronacrisis als een toekomstige omstandigheid gezien. Wel kan worden gedebatteerd over de vraag wanneer precies het omslagpunt is. Eind januari 2020 werden de eerste besmettingen in onder meer Italië en Frankrijk bekend, in februari 2020 vielen daar de eerste doden en eind februari werden in Europa de eerste vergaande overheidsmaatregelen getroffen. Was de coronacrisis in januari of februari 2020 in

27. Schelhaas $2017 / 48.1$ en voor samenloopkwesties par. 48.2. In deze bijdrage ga ik niet apart in op de beperkende werking van de redelijkheid en billijkheid, juist omdat het leerstuk van de onvoorziene omstandigheden daar een species van is en in het kader van de coronacrisis ook vooral een beroep wordt gedaan op onvoorziene omstandigheden.

28. Maar ook heeft geleid tot een exceptionele groei van bepaalde bedrijfstakken, zoals ter zake van desinfecteringsmiddelen, mondkapjes, plexiglas enz., zie Van Boom 2021, p. 129. Zie voorts B.D.A. Zwart, De coronacrisis; nu wél onvoorziene omstandigheden? De lockdown, praktische onmogelijkheden in bouwprojecten en de recessie, TBR 2020/63.

29. De rechter kan dit dus niet ambtshalve doen.

30. Zie o.m. Parl. Gesch. Boek 6 BW, p. 968 (TM) en ook p. 973 (MvA II). 
Nederland al een bestaande situatie, zodat een beroep op art. 6:258 BW voor contracten die ná die periode zijn gesloten, wordt afgesneden? Dat denk ik niet, want op dat moment was nog niet helder wat de omvang van de pandemie was, terwijl bovendien de sinds maart 2020 uitgevaardigde vergaande overheidsmaatregelen nog in het verschiet lagen. Naar mijn mening kan de datum van deze eerste overheidsmaatregelen - 15 maart 2020 - voor Nederlandse contracten in beginsel als ijkpunt worden genomen, omdat die overheidsmaatregelen uiteindelijk de grootste invloed hebben gehad op het maatschappelijke en economische leven en daarmee op bestaande contractuele verhoudingen.

Of partijen ook een regeling hebben getroffen voor - of anders gezegd: rekening hebben gehouden met - een toekomstige omstandigheid, is een kwestie van uitleg. ${ }^{31}$ Het duidelijkste geval is als partijen een clausule hebben opgenomen voor een toekomstige omstandigheid, en bijvoorbeeld hebben bepaald dat toekomstige fluctuaties in vastgoedprijzen geen invloed hebben op contractuele verbintenissen. Vooral in contracten tussen commerciële partijen ('B2B') komen dergelijke clausules regelmatig voor en worden wel lijsten opgenomen met omstandigheden die niet als onvoorziene omstandigheden kunnen worden beschouwd. ${ }^{32}$ Maar in contracten die vóór maart 2020 zijn gesloten, was in de regel geen expliciete contractuele clausule die voorzag in de gevolgen van een pandemie opgenomen. Soms was wel een regeling getroffen voor ziekte of een epidemie, maar daarmee is nog niet gezegd dat die betrekking heeft op de exceptionele gevolgen van deze coronapandemie, waarbij in Nederland vooral de indirecte gevolgen - overheidsmaatregelen - de maatschappij, de economie en daarmee afgesloten contracten hebben beïnvloed. Ik ga hier in paragraaf 4 nader op in.

Maar ook indirect kunnen partijen een bepaalde omstandigheid hebben verdisconteerd in het contract. Want als partijen juist geen regeling hebben getroffen in het contract, terwijl zij weten dat zich een bepaald toekomstig risico heel wel kan voordoen, dan kan ook worden gesteld dat zij rekening hebben gehouden met die situatie: zij hebben er dan bewust voor gekozen dit risico niet contractueel af te dichten en dit dus niet van invloed te laten zijn op de inhoud van hun verplichtingen. Een beroep op art. 6:258 BW staat partijen ook dan niet open. In dit verband speelt de voorzienbaarheid van een omstandigheid wél weer een rol. ${ }^{33}$ Een voorbeeld om dit te verduidelijken. In de huidige omstandigheden is het thans bijvoorbeeld voorzienbaar dat bij bepaalde vakantiebestem-

31. Die uitleg vindt plaats aan de hand van de Haviltex-maatstaf (HR 13 maart 1981, ECLI:NL:HR:1981:AG4158, NJ 1981/635 m.nt. CJHB (Ermes/Haviltex)).

32. Hiermee wordt in feite de werkingssfeer van art. 6:258 BW beperkt. Dat is geoorloofd, zolang het artikel niet in zijn geheel buiten toepassing wordt verklaard: art. 6:250 BW bepaalt dat het artikel van dwingend recht is.

33. Zie ook W.L. Valk, Rechtsgevolgen van de overeenkomsten ten aanzien van partijen, in: Jac. Hijma e.a., Rechtshandeling en overeenkomst (achtste druk), Deventer: Wolters Kluwer 2019/287; Schelhaas 2017/48.1. mingen als gevolg van oplaaiende COVID-19-besmettingen in de nabije toekomst code oranje of zelfs code rood kan worden afgekondigd. Dat heeft tot gevolg dat (vakantie)reizen niet of bezwaarlijk kunnen worden gemaakt. Als thans een reisovereenkomst wordt afgesloten naar een land met code groen of geel, en partijen nemen voor deze situatie niets in hun contract op, dan kan worden gesteld dat zij weliswaar rekening hebben gehouden met het optreden van deze voorzienbare omstandigheid, maar daar geen reden in hebben gezien om het contract te kunnen aanpassen. Een beroep op art. 6:258 BW gaat dan niet op. Maar vóórdat de ernst van de coronacrisis en haar economische gevolgen in Nederland medio maart 2020 naar voren kwamen, kan niet worden volgehouden dat partijen hier stilzwijgend rekening mee hadden gehouden, en er bewust voor kozen geen contractuele voorziening op te nemen. Een goed voorbeeld biedt een vonnis van de rechtbank Amsterdam, waar een hotel verzocht om huurprijsvermindering in verband met het stilvallen van clientèle als gevolg van de coronacrisis en de op basis daarvan uitgevaardigde overheidsmaatregelen:

'De coronacrisis moet, gelet op de omvang daarvan en de gevolgen voor de economie en de maatschappij, in beginsel worden aangemerkt als een onvoorziene omstandigheid. Partijen hebben deze pandemie en de gevolgen daarvan niet in de overeenkomst verdisconteerd en mochten dat redelijkerwijs over en weer ook niet denken. ${ }^{34}$

In een andere zaak, ook over een huurprijsvermindering, wijst de rechtbank Amsterdam er nog op dat het gaat om een wereldwijde gezondheidscrisis 'die heeft geleid tot overheidsmaatregelen (nationaal en internationaal) die het gebruik van een groot deel van de middenstandsbedrijfsruimte voor een langere periode juridisch en/of feitelijk onmogelijk maken, dan wel ernstig belemmeren', en dat daarom niet kan worden aanvaard dat partijen dit in hun contract hebben verdisconteerd. Dat is volgens mij ook waar het hier om gaat. Het feit dat een ziekte of een epidemie kan optreden, is van algemene bekendheid en dáárvan kan nog wel worden beargumenteerd dat een dergelijke algemene omstandigheid stilzwijgend verdisconteerd is in het contract. Maar hier gaat het om iets veel invasievers: een pandemie, die heeft geleid tot een mondiale crisis, gepaard gaand met vergaand overheidsoptreden, dat een groot deel van de economie en hele bedrijfssectoren heeft platgelegd. Dat kent in de historie geen precedent en is dus anders dan alleen een opgetreden ziekte of zelfs epidemie. Voordat kan worden gesteld dat partijen impliciet rekening hebben gehouden met een bepaalde situatie, moet het mijns inziens gaan om een algemeen erkende specifieke situatie die partijen klaarblijkelijk onder ogen hebben gezien, inclusief de (in het geval van corona zeer uitzonderlijke) consequenties daarvan. Dat zal bij de corona-crisis niet snel het geval zijn geweest.

34. Rb. Amsterdam 5 augustus 2020, ECLI:NL:RBAMS:2020:3913. 


\subsection{Ongewijzigde instandhouding kan niet worden gevergd}

Zodra is vastgesteld dat het gaat om een onvoorziene omstandigheid (dus: een toekomstige omstandigheid waar geen rekening mee is gehouden), moet worden beoordeeld of die van dien aard is dat - in de woorden van de wet - 'de wederpartij naar maatstaven van redelijkheid en billijkheid ongewijzigde instandhouding van de overeenkomst niet mag verwachten'. Juist omdát art. 6:258 BW aanzienlijk kan ingrijpen op de contractsvrijheid en de verbindende kracht van overeenkomsten ('pacta sunt servanda'), wordt dit criterium terecht terughoudend toegepast. In de woorden van de Hoge Raad: ${ }^{35}$

'Aan dit vereiste zal niet spoedig zijn voldaan; redelijkheid en billijkheid verlangen immers in de eerste plaats trouw aan het gegeven woord en laten afwijking daarvan slechts bij hoge uitzondering toe (vgl. Parl. Gesch. Boek 6, p. 969). Uit het voorgaande vloeit voort dat de rechter terughoudendheid moet betrachten ten aanzien van de aanvaarding van een beroep op onvoorziene omstandigheden.'

Deze terughoudende toets vormt een fikse drempel voor een geslaagd beroep op onvoorziene omstandigheden. Zo werd de grote mondiale economische kredietcrisis van 2007, en alle gevolgen van dien, als normaal ondernemersrisico gezien dat niet zo ernstig was dat contracten moesten worden aangepast. ${ }^{36}$ Maar de coronacrisis wordt ook in de rechtspraak van een andere orde beschouwd dan deze kredietcrisis en met enige regelmaat wordt thans geoordeeld dat de corona-crisis zodanig ernstige gevolgen heeft, dat naar maatstaven van redelijkheid en billijkheid ongewijzigde instandhouding niet kan worden gevergd. ${ }^{37}$ Wanneer dat zo is, is natuurlijk afhankelijk van de feiten en omstandigheden van het specifieke geval. Het algemene feit dat de coronacrisis in zijn algemeenheid verstrekkend is, is mijns inziens in ieder geval niet voldoende: het moet erom gaan dat ongewijzigde instandhouding van een specifieke contractuele verbintenis gegeven de omstandigheden niet kan worden gevergd. De hoge materiële horde die in art. 6:258 BW besloten ligt, blijft natuurlijk gelden en dient nog steeds terughoudend te worden toegepast. ${ }^{38}$ Dat betekent onder meer dat niet elke onevenwichtigheid die het resultaat is van de coronacrisis aanleiding kan zijn om het contract aan te passen. Dat behoort nu eenmaal tot het feit dat in contracten risico's zijn verdisconteerd, dat niet élke disbalans aanleiding kan zijn om het contract aan te passen, en dat trouw aan het gegeven woord nog altijd het uitgangspunt is. Maar het feit dát

35. Zie o.m. HR 20 februari 1998, ECLI:NL:HR:1998:ZC2587, NJ 1998/493 (Briljant Schreuders/ABP).

36. Vgl. A.T.G.M. Venrooij \& P.S. Bakker, Effecten van de kredietcrisis op (rechtsgevolgen van) financieringsovereenkomsten, O\&F 2009, afl. 3, p. 63-75; T. Hartlief, Crisis? What crisis?, NJB 2013/1603.

37. Rb. Amsterdam 11 juni 2020, ECLI:NL:RBAMS:2020:2914 maakt ook deze vergelijking.

38. Expliciet ook M.V.R. Snel, De coronacrisis als grond voor een rechterlijk ingrijpen in een overeenkomst in verband met het intreden van onvoorziene omstandigheden, WPNR 2020, afl. 7300, p. 763-772, die een aantal voorbeelden noemt waarbij ingrijpen niet geëigend is (bijv. een geringe impact van de coronacrisis) de coronacrisis zo veelomvattend is, het primair een gezondheidscrisis is, dat niemand daarvan een verwijt kan worden gemaakt, pleit wel voor enige solidariteit en kan er mijns inziens wel toe leiden dat de balans sneller doorslaat dan bij minder exceptionele maatschappelijke problemen. ${ }^{39}$ Het zal hierbij wat mij betreft moeten gaan om een fundamentele disbalans die het gevolg is van specifieke coronaomstandigheden.

De meeste zaken waar dit in de rechtspraak aan de orde is, betreffen commerciële huurzaken (B2B), waarbij de huurder zijn clientèle door de coronabeperkingen in aanzienlijke mate zag teruglopen of verdampen en de huurprijs aangepast wilde zien. In veel gevallen oordeelt de rechter dat gezien de fundamentele verstoring van het contractuele evenwicht inderdaad aanleiding bestaat tot een huurprijsaanpassing, ${ }^{40}$ aanvankelijk vooral in kort geding, ${ }^{41}$ thans ook in enige bodemzaken. ${ }^{42}$

Maar ook buiten het huurrecht is in rechte een beroep gedaan op onvoorziene omstandigheden. ${ }^{43}$ Zo in het geval van Corendon en Sunweb, die in 2019 een signing protocol sloten, waaruit wilsovereenstemming blijkt tot een overname door Sunweb van de aandelen van Corendon. Over de inhoud van het overnamecontract (de Share Purchase Agreement) waren partijen het ook eens, en deze was aan het signing protocol gehecht. Om verschillende redenen ontstaat een geschil tussen partijen en weigert Sunweb tot closing over te gaan, onder meer omdat zij meent dat aan enige voorwaarden niet is voldaan. De rechter in kort geding weigert de door Corendon gevraagde voorzieningen, niet zozeer omdat ze inhoudelijk evident onjuist waren, maar gezien 'de Covid-19 crisis zelf die de gehele reisbranche en daarmee zowel de reisorganisaties Sunweb als Corendon bijzonder ernstig treft'. Daardoor zijn de gevolgen van een gedwongen overname niet te overzien, en is een vonnis in kort geding niet op zijn plaats, aldus de rechter. Ook in andere overnamegeschillen werden onvoorziene omstandigheden ingeroepen om contractuele (overname)verplichtingen te omzeilen. In de regel is de rechter niet snel genegen om dit beroep in overnamegeschillen toe te wijzen.

39. Zo ook Snel 2020.

40. Zie voor een mooi overzicht van de mogelijkheden die een pachter op basis van het algemene verbintenissenrecht en specifieke pachtrechtelijke regels toekomt om verlaging van de pachtprijs te realiseren op grond van de coronacrisis: W.L. Valk, Pacht en corona: een verkenning, TvAR 2020, afl. 5, p. 300 e.v.

41. Bijv. Rb. Amsterdam 11 juni 2020, ECLI:NL:RBAMS:2020:2914; Rb. Amsterdam 1 september 2020, ECLI:NL:RBAMS:2020:4752; Hof Amsterdam 14 september 2020, ECLI:NL:GHAMS:2020:2604; Rb. Amsterdam 28 oktober 2020, ECLI:NL:RBAMS:2020:5222; Rb. Den Haag 21 januari 2021, ECLI:NL:RBDHA:2021:461; Rb. MiddenNederland 3 maart 2021, ECLI:NL:RBMNE:2021:837; Rb. Overijssel 8 april 2021, ECLI:NL:RBOVE:2021:1502. Zie verder o.m. R.J.Q. Klomp, Corona en onvoorziene omstandigheden, ORP 2021, afl. 3, p. 4-9; Duijnstee-van Imhoff 2020, p. 439 e.v.; D.J.A. van den Berg, Het jaar 2020 in 20+20 corona-uitspraken, TvHB 2021, afl. 1, p. 4-14.

42. O.m. Rb. Den Haag 21 januari 2021, ECLI:NL:RBDHA:2021:461, JOR 2021/104 m.nt. Schelhaas en ook Klomp 2021, p. 4-5; Rb. Amsterdam 18 mei 2021, ECLI:NL:RBAMS:2021:2478; Rb. Noord-Holland 25 mei 2021, ECLI:NL:RBNHO:2021:4259.

43. Voor het bouwrecht zie Zwart 2020. 


\section{Maandblad}

Zo oordeelde de Netherlands Commercial Court dat de coronacrisis weliswaar een onvoorziene omstandigheid was, maar hier niet zodanig dat afbreuk moest worden gedaan aan de betaling van een break-up fee van $€ 30$ miljoen om onder een transactie ter waarde van $€ 169$ miljoen uit te komen. Ook de uit een signing protocol voortvloeiende verplichting om de Share Purchase Agreement in de retailbranche te ondertekenen werd niet doorkruist door coronaomstandigheden. Anderzijds werd ten aanzien van een overnamecontract van een oogkliniek de coronacrisis succesvol ingeroepen om de closing op een later tijdstip te laten plaatsvinden. ${ }^{44}$

\subsection{Lid 2: voor rekening en risico van wie?}

De laatste horde vormt het tweede lid van art. 6:258 BW: een wijziging van de overeenkomst blijft achterwege indien de omstandigheid voor rekening en risico komt van degene die zich erop beroept. Wanneer hiervan sprake is, is niet helder, maar volgens de tekst moeten in de afweging de aard van de overeenkomst en de in het verkeer geldende opvattingen worden betrokken. Zo kan het feit dat het gaat om een vaststellingsovereenkomst, die bedoeld is om geschillen definitief te beslechten, ertoe leiden dat een onvoorziene omstandigheid toch voor rekening van partijen blijft en geen wijziging van de overeenkomst rechtvaardigt. ${ }^{45}$ Ook het feit dat een partij bijvoorbeeld welbewust geen financieringsvoorbehoud in een contract heeft opgenomen, kan een reden zijn om het niet verkrijgen van financiering door onvoorziene omstandigheden voor risico van deze partij te laten komen. ${ }^{46}$ Tot slot kan het gegeven dat een verzekeringsovereenkomst per definitie bedoeld is om onvoorziene risico's af te dichten, meewegen. Van Boom wijst hier op verzekeringsovereenkomsten van vóór 15 maart 2020, waarin niet is voorzien in de pandemie en dat risico dus evenmin is uitgesloten. Gezien de aard van de overeenkomst - een overeenkomst die verzekert tegen risico's - zal dat echter vermoedelijk voor rekening van de verzekeraar komen. ${ }^{47}$

\subsection{Welke wijziging: heronderhandelen, share the pain?}

Als aan deze vereisten is voldaan, dan kan de rechter de overeenkomst wijzigen of ontbinden. Dat doet hij met een constitutief wijzigingsvonnis. ${ }^{48}$ De rechtsverhouding tussen partijen wordt dus definitief gewijzigd en door de rechter opnieuw

44. Rb. Amsterdam 19 juni 2020, ECLI:NL:RBAMS:2020:3091.

45. In het kader van de coronacrisis: Rb. Midden-Nederland 24 juni 2020 , ECLI:NL:RBMNE:2020:2418.

46. In het kader van de coronacrisis en het niet kunnen verkrijgen van financiering bij een professionele vastgoedtransactie: Rb. Amsterdam 20 mei 2020, ECLI:NL:RBAMS:2020:2647.

47. Van Boom 2021, p. 132.

48. Asser/Sieburgh 6-III 2018/446. vastgesteld. ${ }^{49}$ Deze rechterlijke wijzigingsmogelijkheden zijn vergaand en divers. Wel volgt uit de parlementaire geschiedenis dat bij de wijziging rekening moet worden gehouden met de oorspronkelijke contractuele risicoverdeling. ${ }^{50}$

Wat zijn die wijzigingsmogelijkheden dan? De wet stelt om te beginnen vast dat de rechter de overeenkomst kan ontbinden of wijzigen en daar terugwerkende kracht aan kan verlenen (art. 6:258 lid 1 BW). Verder bepaalt art. 6:260 lid 1 BW expliciet dat voorwaarden kunnen worden verbonden aan de wijziging of ontbinding, bijvoorbeeld het toewijzen van een financiële tegemoetkoming aan de schuldeiser, als de overeenkomst tegen zijn zin wordt ontbonden. Verder (art. 6:260 lid 2 BW) kan de rechter ook bepalen dat, als hij een overeenkomst wijzigt of ontbindt, partijen de mogelijkheid hebben om in plaats daarvan de overeenkomst te ontbinden. Sieburgh noemt het voorbeeld van een verhoging van de koopprijs door de rechter, omdat sprake was van een tijdelijke overmachtstoestand. De koper kan er gezien de hogere koopprijs de voorkeur voor hebben om in plaats hiervan de overeenkomst geheel te ontbinden. Op deze wijze kan aan de belangen van de koper tegemoet worden gekomen. ${ }^{51}$

Maar de rechter kan partijen ook veroordelen om tot heronderhandeling van het contract over te gaan, zodat zij zélf tot een bevredigende oplossing komen. In de literatuur is (onder meer door mij) ook wel bepleit dat een onderhandelingsplicht zou moeten bestaan, ofwel op grond van art. 6:248 lid $1 \mathrm{BW}$ (de aanvullende werking van de redelijkheid en billijkheid), ${ }^{52}$ ofwel binnen de kaders van art. 6:258 BW, ${ }^{53}$ ofwel omdat het contract daartoe verplicht. ${ }^{54}$ Van deze verbintenisrechtelijke plicht zou nakoming kunnen worden gevorderd, en de inzet zou zijn dat een redelijk voorstel niet zomaar mag worden

49. Parl. Gesch. Boek 6 BW, p. 974 (MvA II), waar wordt gesteld dat het feit dat een overeenkomst definitief wordt gewijzigd ook de reden is dat een gerechtelijke uitspraak nodig is, mede met het oog op de belangen van derden. Voor de toepassing van art. 6:248 lid 2 BW, waar art. 6:258 BW een species van is, hoeft dat niet, omdat het daar in de ogen van de wetgever niet gaat om zo'n definitieve wijziging, maar louter om het buiten toepassing laten van een regel in een specifieke situatie, hetgeen minder ingrijpend is en ook in mindere mate leidt tot 'gecompliceerde feitelijke situaties'.

50. Parl. Gesch. Boek 6 BW, p. 970 en 974.

51. Asser/Sieburgh 6-III 2018/446.

52. Het European Law Institute, een onafhankelijke non-profitorganisatie die adviezen geeft in relatie tot Europese juridische problemen, beveelt een dergelijke onderhandelingsverplichting ook an (aanbeveling 13): 'Where, as a consequence of the COVID-19 crisis and the measures taken during the pandemic, performance has become excessively difficult (hardship principle), including where the cost of performance has risen significantly, States should ensure that, in accordance with the principle of good faith, parties enter into renegotiations even if this has not been provided for in a contract or in existing legislation', zie www.european lawinstitute.eu/about-eli/covid-19-principles/.

53. Voor een voorbeeld uit de coronarechtspraak: Rb. Amsterdam 19 mei 2021, ECLI:NL:RBAMS:2021:2478.

54. Zo verplicht in het bouwrecht de UAV partijen tot heronderhandeling bij een kostenverhoging: Zwart 2020, par. 4 . 
verworpen. ${ }^{55}$ Deze onderhandelingsplicht zou er dan toe moeten leiden dat het contract wordt aangepast aan de nieuwe coronaomstandigheden en dat een redelijk wijzigingsvoorstel zou moeten worden aanvaard. ${ }^{56} \mathrm{Wel}$ moet worden bedacht dat het enkele feit dát de corona-crisis contractuele verplichtingen onder druk zet, onvoldoende is om het contract op deze wijze geforceerd open te breken. Dat zou de contractsvrijheid te zeer onder druk zetten. Ook hier zou een drempel moeten worden opgeworpen. Die zou zo kunnen worden ingekleed dat zo'n verplichting pas bestaat als de corona-crisis het contractuele evenwicht ten detrimente van een van de partijen fundamenteel heeft verstoord, en dat de wijziging ook direct verband moet houden met de nadelen van de coronacrisis, niet langer moet duren dan de coronacrisis en rekening houdt met de belangen van beide partijen.

Dat laatste punt brengt mij op de door Tjittes geïnitieerde share the pain-gedachte. ${ }^{57}$ De idee is dat, omdat geen van de partijen blaam treft voor het uitbreken van de pandemie, het nadeel van partijen door de coronapandemie in beginsel bij helfte moet worden verdeeld, mede gezien de menselijke solidariteit die in dit soort mondiale rampen mag worden gevraagd. Als voorbeeld kunnen de hierboven besproken huurzaken dienen: als is vastgesteld dat de huurprijs, gezien de teruggelopen clientèle, 100 te hoog is, dan leidt de share-thepainfilosofie ertoe dat de huurder slechts een huurkorting van 50 krijgt, zodat hij ook een deel van het nadeel blijft dragen. Deze share-the-paingedachte moet er niet toe leiden dat een bestaande disbalans in een contract ook wordt geëlimineerd, want het bestaan van enige disbalans is nu eenmaal de consequentie van het contractenrecht, maar wel dat het nadeel dat is veroorzaakt door de coronacrisis niet op de schouders van een van de partijen komt te rusten. Van Boom ${ }^{58}$ heeft hiertegen ingebracht dat zo'n verdeling van de pijn niet altijd zinvol is, mede omdat (1) partijen vaak al een contractuele voorziening hebben getroffen, (2) hiermee niet al het nadeel van de coronacrisis kan worden weggenomen, (3) partijen vaak meer behoefte hebben aan volledige ontbinding van het contract dan aan wijziging, en (4) het nadeel ook moeilijk is in te schatten. Hij raakt zeker een punt, en de share-the-painfilosofie is geen oplossing voor álle coronaproblemen, ${ }^{59}$ maar ik ben er wel van overtuigd dat als het leerstuk van de onvoorziene

55. Zie R.J.Q. Klomp, Corona en contractenrecht: hoe kunnen partijen tot heronderhandeling worden bewogen?, ORP 2020, afl. 4, p. 12 e.v. voor de nadere inkleding daarvan.

56. Zie nader Schelhaas \& Spanjaard 2020, p. 964.

57. R.P.J.L. Tjittes, Commerciële contracten en corona: uitgangspunt 50/50 verdeling nadeel, gepubliceerd op LinkedIn op 17 maart 2020 en R.P.J.L. Tjittes \& J.V. Tetelepta, Lessen uit de eerste rechterlijke uitspraken over de COVID-19-crisis en onvoorziene omstandigheden en overmacht bij commerciële contracten, Contracteren 2020, afl. 3, p. 108. Zijn voorstel heeft bijval gekregen van o.m. C.E. Drion, Corona en onvoorziene omstandigheden, NJB 2020, afl. 20, p. 1443 (hierna: Drion 2020a); Schelhaas \& Spanjaard 2020, p. 964.

58. W.H. van Boom, Onvoorziene omstandigheden en coronacrisis: \#sharetheburden?, NTBR 2020/11. Voor vergelijkbare bezwaren Snel 2020.

59. In de woorden van Van Boom (2021, p. 134): 'Maar ik vraag mij af of het salomonsoordeel van $50 / 50$ past bij de contextuele benadering die art. 6:258 BW eist.' omstandigheden wordt toegepast, het uitgangspunt zou moeten zijn dat het door de coronacrisis veroorzaakte nadeel niet door één partij volledig moet worden gedragen, maar dat beide partijen daar een aandeel in moeten hebben. Eerder bracht ik met Spanjaard naar voren dat een 50-50-verdeling hierbij een handzaam uitgangspunt kan zijn, maar dat als de contractuele risicoverdeling een andere kant uitslaat, dit er ook toe kan leiden dat het coronarisico ook op een andere wijze moet worden verdeeld. ${ }^{60}$ Maar dát een verdeling moet plaatsvinden, is wat mij betreft in de regel gerechtvaardigd en zou uitgangspunt moeten zijn. Die rechtvaardiging ligt in het feit dat deze mondiale crisis aan niemand kan worden toegerekend, het ook een ongekende crisis is wat betreft herkomst (een pandemie met grote humanitaire gevolgen) en economische omvang (door vergaand overheidsingrijpen zijn hele bedrijfssectoren en delen van de maatschappij stilgelegd of aanzienlijk beperkt). Tegen deze achtergrond zouden uit het oogpunt van solidariteit de gevolgen mijns inziens niet op de schouders van een van de partijen moeten liggen. Ik sluit mij aan bij Drion, die betoogt dat van deze 50-50-verdeling altijd kan worden afgeweken, bijvoorbeeld als blijkt dat de contractuele verhoudingen en verdeling van risico's over en weer anders liggen. ${ }^{61}$ Ook moeten voordelen die zijn behaald door de coronacrisis, in het huurrecht bijvoorbeeld de Tegemoetkoming Vaste Lasten, hierin worden betrokken. ${ }^{62}$

In de rechtspraak wordt de share-the-paingedachte inmiddels vaak gevolgd. In huurrechtzaken wordt hier in uitspraken ook vaak expliciet naar verwezen en wordt op deze grond de gevorderde huurverlaging geregeld slechts gedeeltelijk toegewezen. ${ }^{63}$ Maar ook in andere zaken wijst de rechter op de toegevoegde waarde van deze filosofie. De Netherlands Commercial Court motiveert dat in zijn vonnis over een commercieel overnamegeschil als volgt:

'(...) the answer is clear: the "share the pain" approach, focusing on the parties' contractual equilibrium, is the right way to look at the LOI in the specific circumstances in this case at this early stage. ${ }^{64}$

De rechter paste deze benadering overigens in concreto niet toe, kortweg omdat de clausule die het geschilpunt tussen partijen vormde - betaling van een bedrag als de transactie geen doorgang zou vinden - de risico's tussen partijen al voldoende verdeelde. Maar in algemene zin wordt het uitgangspunt van de share-the-painfilosofie dus vrij breed gedragen, zowel in de rechtspraak als in de literatuur.

60. Schelhaas \& Spanjaard 2020, p. 134.

61. C.E. Drion, Corona en het recht, NJB 2020/761.

62. Vgl. Rb. Amsterdam 9 maart 2021, ECLI:NL:RBAMS:2021:937.

63. Enige voorbeelden: Rb. Den Haag 21 januari 2021, ECLI:NL:RBDHA: 2021:461; Rb. Gelderland 2 februari 2021, ECLI:NL:RBGEL:2021:479; Rb. Gelderland 2 februari 2021, ECLI:NL:RBGEL:2021:479; Rb. Midden-Nederland 3 maart 2021, ECLI:NL:RBMNE:2021:837; Rb. Overijssel 8 april 2021, ECLI:NL:RBOVE:2021:1502.

64. Rb. Amsterdam 29 april 2020, ECLI:NL:RBAMS:2020:2406. 


\section{Pandemieclausules}

In de vorige paragraaf heb ik uiteengezet dat als partijen in hun contract een voorziening hebben getroffen voor de huidige pandemieclausules, het leerstuk van onvoorziene omstandigheden niet opgaat. Ook op ander vlak bewijzen pandemieclausules hun nut. Ik denk aan overmachts- of force-majeureclausules, die bepalen wanneer een tekortkoming toerekenbaar is, en dus wanneer een aanspraak op schadevergoeding bestaat (art. 6:74 BW). Deze clausules zijn in beginsel geldig en afdwingbaar, hoewel natuurlijk altijd de algemene grens van de redelijkheid en billijkheid van art. 6:248 lid 2 BW geldt. Bovendien mogen partijen weliswaar omstandigheden opsommen die niet als onvoorziene omstandigheid kunnen worden aangemerkt, maar zij mogen art. 6:258 BW niet geheel van toepassing uitsluiten (zie art. 6:250 BW).

Vóór het uitbreken van de coronacrisis kwamen clausules die specifiek betrekking hadden op een pandemie en de daaruit voortvloeiende economische consequenties niet vaak voor, simpelweg omdat weinigen rekening hadden gehouden met de mogelijkheid dát een pandemie met dergelijke grote gevolgen zou ontstaan. ${ }^{65}$ Wel kwamen wat algemener geformuleerde clausules voor, op grond waarvan bijvoorbeeld 'ziekte', 'import- en exportverboden' of 'overheidsmaatregelen' werden benoemd, doorgaans om aan te geven dat deze omstandigheden geen aanleiding geven tot een beroep op overmacht of onvoorziene omstandigheden. Het is natuurlijk de vraag of dergelijke algemeen geformuleerde clausules ook de huidige coronacrisis met al haar maatschappelijke en economische gevolgen dekt. Of dat zo is, is een kwestie van uitleg van de overeenkomst, ${ }^{66}$ die plaatsvindt conform de Haviltexmaatstaf. ${ }^{67}$ Daarbij komt het niet uitsluitend aan op de gekozen bewoordingen van de overeenkomst, maar op alle omstandigheden van het geval. ${ }^{68}$

Juist gezien de ingrijpende financiële gevolgen die de coronacrisis op contracten kan hebben, denk ik dat een clausule wel concreet genoeg moet zijn om de gevolgen van de coronacrisis te dekken. Het is wat mij betreft bijvoorbeeld niet zeker of de vermelding dat 'natuurrampen, brand, staking, oorlog, onrust, ziekte en overheidsingrijpen' als overmachtssituaties gelden die in de weg staan aan schadevergoeding of überhaupt geen tekortkoming opleveren, voldoende is om álle gevolgen van de coronacrisis te dekken. Bij de coronacrisis gaat het immers om veel meer dan 'een natuurramp', 'een ziekte' of 'overheidsingrijpen', zodat zo'n algemene overmachtsbepaling niet automatisch betrekking heeft op alle gevolgen van de coronacrisis. Wel kan natuurlijk ook goed worden beargumenteerd dat als

65. Ten tijde van het schrijven van mijn artikel met Spanjaard, net na het uitbreken van de coronacrisis, trof ik slechts een enkele clausule aan die betrekking had op een pandemie, zoals art. 19.8 Algemene verkoop- en leveringsvoorwaarden Samsung. Zie Schelhaas \& Spanjaard 2020, p. 965.

66. H.N. Schelhaas \& W.L. Valk, Uitleg van rechtshandelingen (Preadvies VBR), Zutphen: Paris 2016, p. 84.

67. HR 13 maart 1981, ECLI:NL:HR:1981:AG4158, NJ 1981/635 m.nt. CJHB (Ermes/Haviltex).

68. Valk \& Schelhaas 2016, p. 13-23. werknemers ziek zijn als gevolg van het coronavirus en daardoor niet tijdig kan worden geleverd, dit onder deze clausule valt. Ook de situatie dat een overheidsoptreden ertoe leidt dat goederen niet of te laat worden geleverd omdat een hele bedrijfstak als gevolg van het coronavirus is gesloten, kan mogelijk onder het bereik van de bovenstaande clausule worden gebracht. Het blijft natuurlijk belangrijk om de pandemieclausules nauwkeurig op te stellen, zodat duidelijk is wat er wel en niet onder valt.

In dit verband verdient de belangrijke Material Adverse Change (MAC)-clausule, die vaak in omvangrijke overnamecontracten wordt opgenomen, aandacht. Deze clausule geeft de koper de mogelijkheid om te ageren bij onvoorziene omstandigheden na signing maar voor closing, ${ }^{69}$ die de waarde van de doelvennootschap ${ }^{70}$ aanzienlijk verminderen. Is de corona-crisis, die de waarde van de doelvennootschap negatief beïnvloedt, dan zo'n onvoorziene omstandigheid die een MAC-bepaling kan activeren? Tjittes en Hogeterp hebben overtuigend betoogd dat een algemene MAC-clausule, waarbij geen melding wordt gemaakt van de corona-crisis, niet veel soelaas zal bieden. ${ }^{71}$ In de eerste plaats omdat de corona-crisis waarschijnlijk niet structureel is en de MAC-clausule juist betrekking heeft op structurele waardeverminderingen. In de tweede plaats omdat overheidsmaatregelen, die uiteindelijk de oorzaak zijn van de economische neergang van een doelvennootschap, vak zijn uitgezonderd van een MAC-clausule. Bovendien signaleren beide auteurs dat het niet eenvoudig is om causaal verband aan te tonen tussen de coronacrisis en de waarde van de doelvennootschap.

Maar sinds het uitbreken van de corona-crisis worden specifieker pandemieclausules in contracten opgenomen. Een interessante clausule is de volgende, die Bouwend Nederland net ná het uitbreken van de coronacrisis opstelde, en die vooral in het voordeel is van aannemers: $:^{72}$

\section{'Corona clausule}

Partijen zijn op de hoogte van het coronavirus en de onzekerheid die dit met zich meebrengt voor de nakoming van de verplichtingen van partijen uit deze overeenkomst.

De gevolgen van het coronavirus, alsmede de gevolgen van de in verband hiermee door de overheid gegeven en nog te geven aanbevelingen, resp. door de overheid genomen en nog te nemen maatregelen, zijn daarom niet verdiscon-

69. Bij een transactie die bestaat uit de overname van aandelen, bestaan twee belangrijke momenten: het ondertekenen ('signing') van het overnamecontract (de Share Purchase Agreement) en de daadwerkelijke overdracht ('closing') van die aandelen. Tussen beide momenten kan veel tijd zitten, variërend van weken tot maanden tot meer dan een jaar.

70. Oftewel, de vennootschap wier aandelen worden gekocht en geleverd.

71. R.P.J.L. Tjittes \& A. Hogerterp, De coronacrisis en MAC-clausules in M\&A-contracten, Ondernemingsrecht 2020, afl. 7, p. 366-377.

72. Zie https://ploum.nl/kenniscentrum/nieuws/nieuwe-clausules-vooraannemingsovereenkomsten-in-tijden-van-de-coronacrisis. 
teerd in de aanneemsom/prijs voor het werk resp. het (meerjarig) onderhoud.

Partijen verklaren over en weer dat de gevolgen van het coronavirus een omstandigheid vormen die de opdrachtnemer niet kan worden toegerekend, en dat opdrachtnemer voor die gevolgen recht heeft op kostenvergoeding en termijnsverlenging.'

Met deze clausule wordt zeker gesteld dat de opdrachtnemer later nog een kostenstijging in zijn prijs kan doorberekenen, en wordt ook bepaald dat de gevolgen van het coronavirus voor de opdrachtnemer overmacht opleveren en dus niet leiden tot aansprakelijkheid. Tegelijkertijd betekent deze clausule dat partijen een voorziening hebben getroffen voor coronagerelateerde problemen. Een beroep op onvoorziene omstandigheden wordt zo dus beperkt. Ook een clausule op grond waarvan onder overmacht in ieder geval niet wordt verstaan 'epidemieën, pandemieën, (overheids)maatregelen vanwege epidemieën en/of pandemieën', ${ }^{73}$ is mijns inziens voldoende concreet en breed genoeg om de gevolgen van een volgende pandemie niet van invloed te laten zijn op contractuele verbintenissen, of om een nieuwe coronagolf te kunnen weren.

Ook in andere contracten komen nu met regelmaat pandemieclausules voor, ${ }^{74}$ net als $9 / 11$ ervoor heeft gezorgd dat in overnamecontracten bomaanslagen werden genoemd als omstandigheid die geen aanleiding geeft om een contract aan te passen, en er na 2004, toen vooral Azië werd getroffen door hevige tsunami's, in contracten tsunamiclausules werden opgenomen. ${ }^{75}$

Het beginsel van de contractsvrijheid heeft tot gevolg dat deze clausules in beginsel geldig en afdwingbaar zijn, of ze nu betrekking hebben op overmacht (en dus op een eventuele schadevergoedingsverplichting) of op onvoorziene omstandigheden (en dus aanpassing van een contract op basis van art. 6:258 BW verhinderen). Een pandemieclausule is bedoeld om de bindende kracht van overeenkomsten te versterken en heeft dat effect meestal ook. Zij zet de wijzigingsbevoegdheid van de rechter in de regel buitenspel, en voorkomt dat de debiteur zich op overmacht kan beroepen. De coronacrisis heeft er zo voor gezorgd dat een nieuwe contractclausule het licht heeft gezien: de pandemieclausule.

\section{Reflectie}

De voorgaande analyse heeft aan het licht gebracht dat de contractsvrijheid door de coronacrisis in menig geval onder druk is komen te staan.

73. Zie de algemene inkoopvoorwaarden diensten, Erasmus Universiteit Rotterdam: www.eur.nl/media/89741.

74. In internationaal verband zie D. Philippe, The Impact of the Coronavirus Crisis on the Analysis and Drafting of Contract Clauses: Force Majeure, Hardship and Deferral of Obligations, in: E.H. Hondius (red.), Coronavirus and the Law in Europe, Intersentia: Cambridge/Antwerpen/Chicago 2021, p. 527-553.

75. Zie Tjittes \& Hogerterp 2020, p. 368.
In de eerste plaats is duidelijk dat vaccinatie- en testverplichtingen weliswaar in beginsel in contracten kunnen worden opgenomen, maar dat deze vrijheid wordt begrensd, omdat hier mensenrechten in het geding zijn en zulks ook strijdig kan zijn met het Nederlandse uitgangspunt dat een vaccinatieplicht niet bestaat.

In de tweede plaats is naar voren gekomen dat het leerstuk van de onvoorziene omstandigheden door de coronacrisis nieuw leven is ingeblazen en geregeld onderwerp is van rechtspraak. Het leerstuk wordt toegepast om harde gevolgen van de coronacrisis te mitigeren. Hierbij worden in de rechtspraak in menig geval de nadelige gevolgen van de corona-crisis over partijen verdeeld. Dat is wat mij betreft gerechtvaardigd. Natuurlijk, de fundamenten van het contractenrecht moeten in acht worden genomen, ook als contracten door de coronacrisis zijn gaan knellen. De contractsvrijheid, trouw aan het gegeven woord en een terughoudend ingrijpen in contractuele verhoudingen, vooral in B2B-verhoudingen, zijn nog steeds fundamenten van het contractenrecht. Maar de ernst, aard en inhoud van de coronacrisis vergen wel dat deze beginselen niet automatisch moeten worden toegepast en dat uitzonderingen moeten worden gemaakt. ${ }^{76}$ Dat wordt wat mij betreft gerechtvaardigd door de gedachte dat het hier niet om zomaar een crisis gaat, en niet zómaar om contracten die onder druk staan, maar om een ongekende mondiale gezondheidscrisis die tot veel doden en zieken en tot ongekend verstrekkende overheidsinterventies heeft geleid. Onder die omstandigheden is een inbreuk op de contractsvrijheid gerechtvaardigd, om zo de nadelen van deze exceptionele en disruptieve economische, humanitaire en maatschappelijke crisis te verdelen.

De derde in deze bijdrage omschreven ontwikkeling die de coronacrisis relateert aan de contractsvrijheid, is de komst van coronaclausules. Deze beweging is reactief en versterkt juist de contractuele band en de contractsvrijheid. Deze clausules trachten de contractuele band te verstevigen, om tegenwicht te bieden aan juridische technieken die op grond van de coronacrisis bressen slaan in het adagium van pacta sunt servanda. 